\title{
INFLUENCE AS A MEANS OF CONVEYING EMOTION IN THE ROMANIAN INTERWAR LITERATURE
}

A quantitative approach to the literary reviews written in the Romanian cultural space during the interwar period ${ }^{1}$ is significant for several reasons. Firstly, the directly proportional increase of reviews and novels illustrates a rising book market. Both the novels with fewer than five reviews and the ones having more than sixteen reach their peak number in 1935 (see the graph below), two years after the banner year of the Romanian novel.

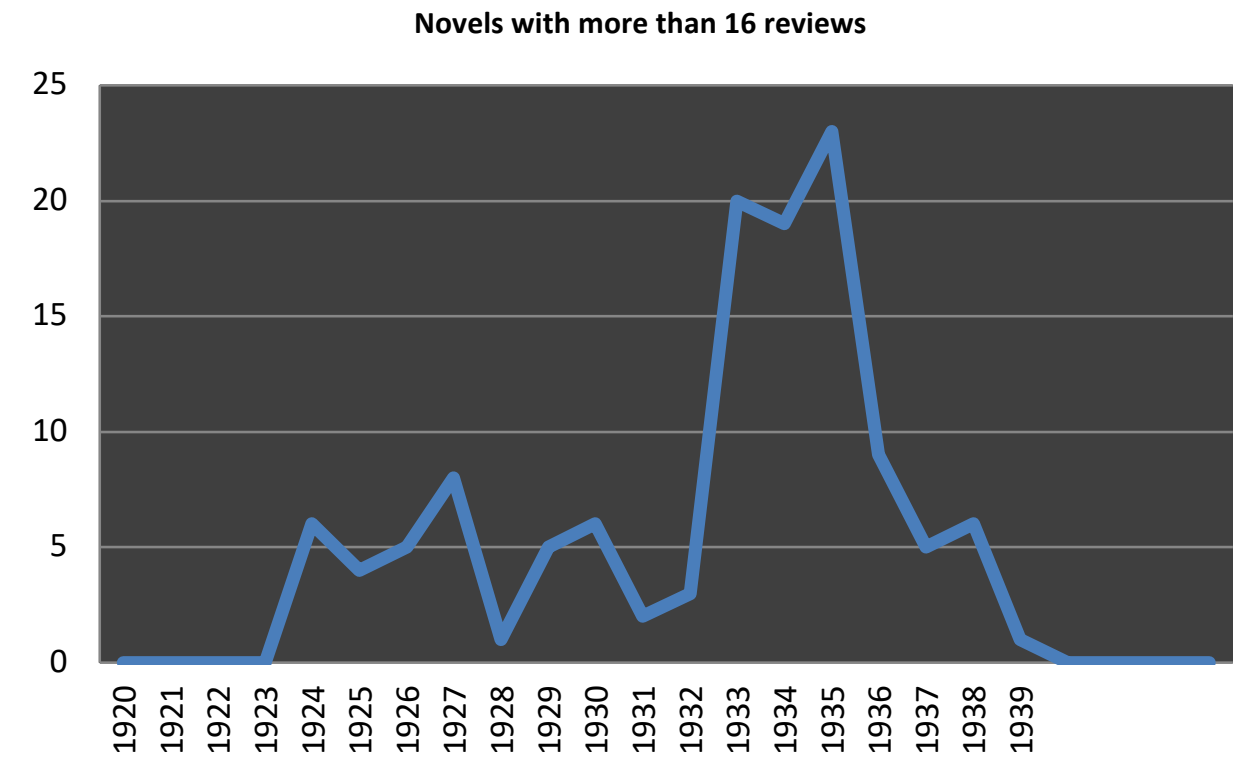

Secondly, the novels with a rich critical corpus are so numerous in the $1930 \mathrm{~s}$ that a fair assessment of the situation requires the creation of a new category, comprising the novels whose reception exceeds twenty-five reviews. Worth mentioning here in 1932 are Bizu (by E. Lovinescu), Răscoala [The Uprising] (by Liviu Rebreanu), Europolis (by Jean Bart), Adela (by Garabet Ibrăileanu) and Patul lui Procust [The Bed of Procrustes] (by Camil Petrescu), published in 1933. In 1934,

\footnotetext{
${ }^{1}$ The statistics presented in this paragraph are the results of the student internship I have conducted at the "Sextil Puşcariu" Institute of Linguistics and Literary History, in Cluj-Napoca, in the academic year 2014-2015.
} 
this twenty-five plus classification includes Ochii Maicii Domnului [Our Lord's Mother's Eyes] (by Tudor Arghezi), Mite (by E. Lovinescu), Foc in hanul cu tei [Fire in the Lime Tree Inn] (by I. Peltz) and Mâl [Mud] (by Isaiia Răcăciuni). In 1935, the peak year for reviews, the subsequent books had an exceptional critical reception: Huliganii [The Hooligans] (by Mircea Eliade), Bălăuca (by E. Lovinescu), Donna Alba (by Gib Mihăiescu), Logodnicul [The Fiancé] (by Hortensia Papadat-Bengescu), Luceafärul sau romanul lui Eminescu [The Evening Star or Eminescu's Novel] (by Cezar Petrescu) și Cara-su (by I. Valerian).

From the statistics above we can observe the following dynamics: on one hand, the lack of correlation between the category of the abundantly reviewed and the presence in Romanian literary canon in the case of Jean Bart, I. Peltz, Isaiia Răcăciuni, Gib Mihăiescu, Cezar Petrescu and I. Valerian and, on the other hand, the inclusion of already well-established names in the 1930s. Liviu Rebreanu and Hortensia Papadat-Bengescu had published all their significant works by 1932 and 1935, respectively. E. Lovinescu had concluded his magnum opus in his four volumes of Istoria literaturii române contempoane [History of Romanian Contemporary Literature]. As for G. Ibrăileanu, he had published Scriitori și curente [Writers and currents], Scriitori români și străini [Romanian and Foreign Writers] and Studii literare [Literary Studies] by 1930, three major critical volumes in Romanian literature. A prolific publicist, Camil Petrescu had debuted as a novelist three years before, with Ultima noapte de dragoste, intâia noapte de război [The Last Night of Love, the First Night of War]. On the poetic front, Tudor Arghezi had published two volumes that would prove influential, Cuvinte potrivite [Matched Words] (1927) and Flori de mucigai [Flowers of Mold] (1931).

Whether they stand the test of time by entering the literary canon, or remain confined to being novelists of their own time, these top 25 writers can acquire the label of "écrivain préféré"2. In the words of Dominique Dupart in "Prénom et nom de l'écrivain préféré: Jacques Derrida", though its appearance is given through the name, preference can only be assigned through writing and the revelation it brings to its reader. Thus, "écrivain préféré" indicates a direction, paves the way towards recognition and identification and, most importantly, is the intercessor for an aesthetic relation.

The fascination for proper names in the critical reception of interwar novels is also signaled by Eugène Ionesco in a caustic analysis to Ultima noapte de dragoste, intâia noapte de război. According to him, while lacking literary value, Camil Petrescu's novels succeed in seducing not only the readers, but also the critics,

\footnotetext{
${ }^{2}$ Marielle Macé, Christophe Pradeau (eds.), "L’Écrivain préféré”, Fabula LhT, 4, 2008, accessed 2 April 2019, http://www.fabula.org/lht/4/

3 Dominique Dupart, "Prénom et nom de l'écrivain préféré: Jacques Derrida", Fabula LhT, 4, 2008, accessed 2 April 2019, http://www.fabula.org/lht/4/dupart.html
} 
through a process of "collective suggestion"4. If by 1930, Camil Petrescu had undertaken aesthetic, cultural, literary and dramatic polemics, being a "lightning rod of Romanian literature", after a prolonged literary adolescence, "he tragically realized that, in one way or another, he had to fulfill his promises, to create a role for himself" . At the heart of this project, says Ionesco, lies "his literary friendship with everyone up to that moment"7. Thus, as a means of collective suggestion, friendship implies, according to the nihilist writer, the emotional drift of those involved in the critical act, through both compassion and habit.

The same influence, but in the opposite direction, this time exerted by Camil Petrescu himself over criticism, is signaled by Eugen Lovinescu in the analysis of Anton Holban's play, Oameni feluriți [Various People]. Important details of the play are overlooked by the reviewers of the time because "Camil Petrescu, always the egocentric [...] influenced the critics' reception of Holban's play"8. Yet, the relationship between Anton Holban and Camil Petrescu goes back further than that, close to the former's literary debut. In the second issue of Azi [Today] magazine, Holban emphasizes the importance of Camil Petrescu's attitude in his literary fate:

In the beginning, I had no conviction that Oameni feluriți would be any good. The certainty that everyone thinks the best about themselves made me feel discouraged. The enthusiasm of Mr. Camil Petrescu (who has read the manuscript, without knowing the author) has certainly supported me. And later on, the appreciation of Hortensia PapadatBengescu and E. Lovinescu, Rebreanu and Eftimiu?.

A similar situation is presented by Camil Baltazar, in Contemporan $\mathrm{cu}$ ei [Contemporary with Them], a volume consisting of portraits of the interwar writers. According to Baltazar, the friendship between himself and Camil Petrescu, stems, above all, from the gratitude that the former owes to the latter for getting his first poems published by Lovinescu. Their relationship is, at the same time, "under the sign of a great affection, with all its fluctuations and crises, inherent in relations that are permanently under the dominion of continuous disputes and controversies"10.

The consolidation of friendships in the Sburătorul literary circle is a well-known fact. What is surprising for this era of literary apex, though, is precisely the

${ }^{4}$ Eugène Ionesco, $\mathrm{Nu}[\mathrm{No}]$. Traducere de Marie-France Ionesco. Postfață de Mircea Vasilescu, București, Humanitas, 2011, p. 94. When not specified otherwise, the English translations from Romanian are mine.

${ }^{5}$ Ibidem, p. 89.

${ }^{6}$ Ibidem, p. 90.

${ }^{7}$ Ibidem, p. 91.

${ }^{8}$ E. Lovinescu, Agende literare [Literary Agenda], I. Ediție de Monica Lovinescu și Gabriela Omăt. Prefață și note de Alexandru George, București, Minerva, 1993, p. 121.

${ }^{9}$ Anton Holban, "Confidențe preliminare" ["Preliminary Confidences"], Azi, III, 1934, 2, p. 1038.

${ }^{10}$ Camil Baltazar, Contemporan cu ei: amintiri și portrete [Contemporary with Them: Memories and Portraits], București, Editura pentru Literatură, 1962, p. 79. 
genuineness through which friendship, emotions, and character traits are valorised in literary judgements.

The declared enthusiasm of Camil Petrescu, that influenced Holban's literary destiny, is the reason for the article "Mihail Sebastian sau despre prietenia literară" ["Mihail Sebastian or about Literary Friendship"], one of the most illustrative testimonies on the status of literary friendships between the two wars. The editor of the magazine where Camil Petrescu intended to publish his review of the novel Femei [Women] by Mihail Sebastian told him that it would be impossible to publish his article in the current issue, as it already contained a review by Sebastian of Patul lui Procust. The indignation spurred by this event determined the author of Patul lui Procust to add to his review an introduction where he invokes and defines literary friendship as follows:

After all, it is not a cheese stand that has gathered and kept us together for so long, nor the mutual delight for the alleged physical benefits, of course. [...] This is a strictly literary friendship of people who believed in writing, who attempted the dissolution of all doubts and searched for solutions through shared effort ${ }^{11}$.

Therefore, subject to common artistic principles and uncertainties, friendships between writers do not imply concessions. "We are not a corporation defined by some common goal" 12 , notes Camil Petrescu, drawing a demarcation line between the guilds of writers and the capitalist groups (corporations), that were in full ascension in early $1918^{13}$. "It would be absurd to assume that the writers are spiritual clockwork robots, incapable of indicating another time than their own"14, notes, as follows, the aforementioned author, emphasizing empathic reading. However, Camil Petrescu's enthusiasm for Femei comes from commonalities with his own writing and literary options:

Femei is a book so close to my steadfast preferences, an incident from the same tenuous area of discontinuous psychology, of abstract substantiality, of experience lacking the geometrical certainties of the solids, that has formed the directing point for a systematic activity ${ }^{15}$.

Within these literary friendships, in the emotions that ensure the cohesion of the community of writers and in their interference with the shared fondness for French literature, psychology and philosophy, sciences barely institutionalized in 1920's

\footnotetext{
${ }^{11}$ Camil Petrescu, Opinii și atitudini [Opinions and Attitudes]. Antologie şi prefaţă de Marin Bucur, București, Editura pentru Literatură, 1962, p. 206.

${ }^{12}$ Ibidem, p. 207.

${ }^{13}$ As noticed by Cornel Ban, "Între capitalism și mercantilism”, in Dependență și dezvoltare. Economia politică a capitalismului românesc [Dependency and Development. The Political Economy of Romanian Capitalism], Cluj-Napoca, Tact, 2014.

${ }^{14}$ Camil Petrescu, Opinii, p. 207.

${ }^{15}$ Ibidem, p. 208.
} 
Romania, lie some of the reasons why Proustianism ${ }^{16}$ is successfully imbued in the Romanian collective mentality at the beginning of the 20th Century. Although perceived as a natural, organic step in the evolution towards authenticity and introspection in Romanian literature, both by writers and critics of the time, Proustianism is, in fact, subjected to a process of inculcation at the very moment of its materialization in discourse. A very good comparison that we can apply to Romanian Modernism to describe this process belongs to Cristophe Granger. In Le monde comme perception, he says that the frequent tasting of various foods brought from the colonies facilitates the gradual acclimatization and acculturation of exotic cuisine in interwar Paris. The basis for this tasting, according to the author, is a process of inculcation, which works through a continuous effort of anamnesis, a permanent search for "the initial meaning of the flavor" ${ }^{17}$ and, at the same time, a process of "slow domestication of tasting rites"18.

In order to accurately observe this mechanism, we exit the comfort zone of the friendship born amidst the Sburătorul circle and Lovinescu's syncronism, and focus on G. Ibrăileanu, a declared poporanist ${ }^{19}$ until 1920, known as an opponent to the evolutionary ideas of E. Lovinescu. In an article from 1925, "Influențe străine și realități naționale" ["Foreign Influences and National Realities"], G. Ibrăileanu notes:

Should we not finally understand that we cannot have any literature other than that fitting our reality? An Anatole France or a Marcel Proust are inaccessible to us. It is not that we can't have great native talents, not that we cannot have superior intelligentsia of our own, that we can't have satirical spirits, people of spirit, observers of their own soul and the soul of others. There is something else. We do not have the national prerequisites for a France and a Proust. France requires a long cultural tradition - a specific one: French and Greek-Latin, and an intellectual environment saturated with civilization and culture. Proust assumes a long cultural tradition, an overrefined intellectual environment - and a cultivated, fine, sophisticated 'society', where the spirit of observation and analysis can develop -a society that requests this spirit from the observer and listens to $\mathrm{it}^{20}$.

The quote above is important for two reasons. Firstly, the author rejects the possibility of importing on sterile ground the writers who are born in a society with a Greek-Latin literary tradition. There are predefined steps that a culture must follow to reach Proustian heights. Secondly, through "a society that requests this spirit from

\footnotetext{
${ }^{16}$ Term used by the Romanian interwar writers to describe the character of being Proustian.

${ }^{17}$ Christophe Granger, "Le monde comme perception", Vingtième Siècle. Revue d'histoire, 2014, 3, p. 8 . 
the observer and listens to it" ${ }^{\prime 21}$, the vicious circle looks as follows: by requesting them, the society is the one who rears these observers of inner life, and it is also the society, seen by Ibrăileanu in terms of maternal figure, that has the task of following and understanding them. Although Ibrăileanu emphasizes the lack of a favorable social framework in Romanian literature, he draws a different conclusion: even in an ideal society, these observers of the soul are a construct, not the result of a course regarded as natural in the history of literature. A year later, in "Note pe marginea unor cărți”, Ibrăileanu returns to the issue of importing in literature.

We are the students of the French literature school and, now that the most particular, the most specific French writers distinguish themselves through analysis and especially through moralism, our writers should learn this from the French, if that is something that can be learned at all. Maybe it can. Namely, through reading and familiarization the taste for psychology can be developed, or, more precisely, one can strengthen the tendency towards analysis and moralism, present, at a rudimentary level, in every human being ${ }^{22}$.

According to Ibrăileanu, Marcel Proust and William James are the epitome of psychology ${ }^{23}$. The argument the author proposes in the above fragment is precisely the idea he was opposing a year ago, namely the import of the Proustian novel into the Romanian space. Surprisingly for a critic labeled as a nationalist, the exchange he proposes is not the one of imitation, assimilation and interpenetration ${ }^{24}$, as Lovinescu suggests through synchronism, but rather, as in Cristophe Granger's example, the exchange brought by the process of tasting ("reading") and inculcation ("familiarization").

The universal inclination towards analysis and moralism ("the tendency towards analysis and moralism, that is present, at a rudimentary level, in every human being" ${ }^{25}$ ), which would facilitate the import of psychology into Romanian literature, is reinforced in the interwar period with ideas that Pascale Casanova places under the concept of "neutrality or denationalization of Paris/ French" symptomatic in this regard and in tune with contemporary theories is Mihai D. Ralea's article, written in 1928. "France is closest to anybody's homeland"27, says Ralea, and "French civilization belongs more to humankind than to itself" ${ }^{28}$. France imposes itself in the Romanian literary space, just like in the rest of Central and Eastern Europe, not through its national character, not by what could be seen as

${ }^{21}$ Ibidem, p. 280.

22 G. Ibrăileanu, "Reproducerea realităţii" ["The Reproduction of Reality"], in Studii literare. Antologie, studiu introductiv și note de Ion Bălu, București, Albatros, 1976, p. 227.

${ }^{23}$ G. Ibrăileanu, Scriitori români și străini, Iași, Viața Românească, 1926, p. 227.

24 E. Lovinescu, Istoria literaturii române contemporane [History of Romanian Contemporary Literature], III, Minerva, București, 1981, p. 270.

${ }^{25}$ G. Ibrăileanu, "Reproducerea”, p. 124.

${ }^{26}$ Pascale Casanova, The World Republic of Letters. Translated by M.B. DeBevoise, London, Harvard Univeristy Press, 2004, p. 45.

${ }^{27}$ Mihai D. Ralea, Perpective [Perspectives], București, Editura Literară a Casei Școalelor, 1928, p. 126.

${ }^{28}$ Ibidem, p. 126. 
specifically French, but by cosmopolitanism ${ }^{29}$. To further Ralea's theory, it is not through political collaboration that France became the "subsidiary of humanity"30, but through the freedom it offers to writers aspiring to autonomy ${ }^{31}$.

In addition to the image of an international France, there is also a Proust seen not only through the lenses of specific French syntax, but through what makes him an European writer ${ }^{32}$. "I was amazed, [writes Ionesco] by the fact that Proust, his psychology, morality, aesthetics and spirituality are 'my own'. His subtleties and sensitivity belong to me, they belong to us, they are actual, they are ours. That's why Proust cannot even belong to himself ${ }^{\prime 33}$. Anton Holban, on the other hand, defensive against the imputation of Proust's influence, says: "I certainly envy Proust (if a living man can envy a dead one) for many pages I might have written identically. For example, the Vinteuil Sonata or Albertina's sleep" ${ }^{34}$.

The fact that Mihail Sebastian sees in Holban the same Proustian temperament ${ }^{35}$, the connection that Camil Petrescu notices between Femei by Mihail Sebastian and Proust through "the impression of life flowing" 36 , the unanimity regarding Papadat Bengescu's deficitary Proustianism, polemics on Camil Petrescu's novels on whether they are results of Stendhal's influence or traces of Proustianism, Holban's assertion of the influence on his own writing exerted by Hortensia PapadatBengescu $^{37}$, the jealousy of Camil Petrescu that befell anyone aiming to translate Proust $^{38}$ are all attempts at appropriating the French writer. Thus, the import of the Proustian novel is not necessarily a consequence of Lovinescu's progressivism, as surprisingly similar ideas can be found in the works of nationalist writers such as G. Ibrăileanu and Mihai D. Ralea, but mostly an effect of the French symbolic supremacy that was felt at the time in the Central and East-European peripheral spaces $^{39}$.

It is, first of all, Proustianism used as the basis for the Romanian novel (through its openness to psychology, analysis, authenticity, objectivity), as seen in Ibrăileanu's studies, and then, Proustianism used as a membership card for the interwar community of writers. The affective connections of literary friendships and

\footnotetext{
${ }^{29}$ Pascale Casanova, The World, p. 68.

${ }^{30}$ Ibidem, p. 125.

${ }^{31}$ Ibidem, p. 87.

${ }^{32}$ Ibidem, p. 110.

${ }^{33}$ Eugène Ionesco, Război cu toată lumea: publicistica românească [At War with Everybody: the Romanian Journalistic Writings], 1. Ediție îngrijită și bibliografie de Mariana Vartic şi Aurel Sasu, București, Humanitas, 1992.

34 Anton Holban, Pseudojurnal: corespondență, acte, confesiuni [Pseudojournal: Correspondence, Acts, Confessions]. Ediție îngrijită de Ileana Corbea și N. Florescu. Prefață și note de Nicolae Florescu, București, Minerva, 1978, p. 195.

${ }^{35}$ Ibidem, p. 195.

${ }^{36}$ Camil Petrescu, Opinii, p. 211.

${ }^{37}$ Anton Holban, Pseudojurnal, p. 57.

${ }^{38}$ Ibidem, p. 117.

${ }^{39}$ Pascale Casanova, The World, p. 178.
} 
the status of "écrivain préféré" 40 held by some writers within and without the Sburătorul circle (if we take into consideration Ibrăileanu's placement in the top 25) are all the facilitators of the import of Marcel Proust's novel. This is done initially in a snobbish manner, by including $\dot{A}$ la recherche $d u$ temps perdu in the talks at the literary circle (see Agende literare, by Eugen Lovinescu) and through the gesture of reading Proust on the train and on holiday, and then as a foundation, through exhaustive analysis and theoretical studies, such as "Noua structură şi opera lui Marcel Proust", written by Camil Petrescu in the 1930's.

Thus, far from being a comprehensive analysis of this phenomenon, my paper paves the way for a discussion on how Marcel Proust is brought into Romanian literature. Due to its extensive use by critics as a term of comparison and description of Romanian writers, Proust's influence ends up as a given, a by-product of a Francophone Romanian literary society.

\section{WORKS CITED}

BALTAZAR, Camil, Contemporan cu ei: amintiri și portrete portrete [Contemporary with Them: Memories and Portraits], București, Editura pentru Literatură, 1962.

BAN, Cornel, Dependență și dezvoltare. Economia politică a capitalismului românesc [Dependency and Development. The Political Economy of Romanian Capitalism], Cluj-Napoca, Tact, 2014.

CASANOVA, Pascale, The World Republic of Letters. Translated by M.B. DeBevoise, London, Harvard University Press, 2004.

DUPART, Dominique, "Prénom et nom de l'écrivain préféré : Jacques Derrida", Fabula LhT, 4, 2008, accessed 2 April 2019, http://www.fabula.org/lht/4/dupart.html.

GRANGER, Christophe, "Le monde comme perception", Vingtième Siècle. Revue d'histoire, 2014, 3, pp. 3-20.

HOLBAN, Anton, "Confidențe preliminare" ["Preliminary Confidences"], Azi, III, 1934, 2, p. 1038.

HOLBAN, Anton, Pseudojurnal: corespondență, acte, confesiuni [Pseudojournal: Correspondence, Acts, Confessions]. Ediție îngrijită de Ileana Corbea și N. Florescu. Prefață și note de Nicolae Florescu, București, Minerva, 1978.

IBRĂILEANU, G., "Influențe străine și realități naționale" ["Foreign Influences and National Realities"], Viața Românească, XVII, 1925, 2.

IBRĂILEANU, G., "Reproducerea realității" ["The Reproduction of Reality"], in Studii literare [Literary Studies]. Antologie, studiu introductiv și note de Ion Bălu, București, Albatros, 1976.

IBRĂILEANU, G., Scriitori români și străini [Romanian and Foreign Writers], Iași, Viața Românească, 1926.

IONESCO, Eugène, $N u[N o]$. Traducere de Marie-France Ionesco. Postfață de Mircea Vasilescu, București, Humanitas, 2011.

IONESCO, Eugène, Război cu toată lumea: publicistica românească [At War with Everybody: the Romanian Journalistic Writings], I. Ediție îngrijită și bibliografie de Mariana Vartic şi Aurel Sasu, București, Humanitas, 1992.

LORDON, Frédéric, La société des affects. Pour un structuralisme des passions, Paris, Seuil, 2013.

LOVINESCU, E., Agende literare [Literary Agenda], I. Ediție de Monica Lovinescu și Gabriela Omăt. Prefață și note de Alexandru George, București, Minerva, 1993.

\footnotetext{
${ }^{40}$ Dominique Dupart, "Prénom".
} 
LOVINESCU, E., Istoria literaturii române contemporane [History of Romanian Contemporary Literature], III, Minerva, București, 1981.

MACÉ, Marielle, PRADEAU, Christophe (eds.), “L’Écrivain préféré”, Fabula LhT, 4, 2008, accessed 2 April 2019, http://www.fabula.org/lht/4/.

PETRESCU, Camil, Opinii și atitudini [Opinions and Attitudes]. Antologie și prefață de Marin Bucur, București, Editura pentru Literatură, 1962.

RALEA, Mihai D., Perpective [Perspectives], București, Editura Literară a Casei Școalelor, 1928.

\section{INFLUENCE AS A MEANS OF CONVEYING EMOTION IN THE ROMANIAN INTERWAR LITERATURE \\ (Abstract)}

The Romanian literature and culture at the beginning of the $20^{\text {th }}$ century is marked on the level of affective configurations by two imports: (1) philosophy, as a science of the soul, and (2) Marcel Proust, as an analyst of inner life. Starting from a general frame of viewing emotions in relation to an effort of descent into spiritual world, we will investigate the role of influence in the development in Romanian interwar literature of a vocabulary of affects, taken from the French space through these two aforementioned means of import. We define the influence as a "diffuse, almost indiscernible, often unconscious" phenomenon (Maxime Decout, Qui a peur de l'imitation), which requires from the reinterpreting author an import, a selection and, finally, an adaptation, and we relate it to Maurice Halbwachs' theory of emotions, that are described as an instrument for ensuring the cohesion of the group and, at the same time, the preservation of society (L'expression des émotions et la société), and to Frédéric Lordon's theory, where affects are seen as the effect of the structure in which the individual is involuntarily constrained (La société des affects).

Keywords: Romanian literature, Marcel Proust, affective configuration, influence, comparative literature.

\section{INFLUENȚA CA MIJLOC DE TRANSMITERE A EMOȚIILOR ÎN LITERATURA ROMÂNĂ INTERBELICĂ \\ (Rezumat)}

Cultura și literatura română de la începutul secolului al XX-lea sunt caracterizate la nivelul configurărilor afective de două fenomene de import: (1) filozofia, ca știință a sufletului și (2) Marcel Proust, în calitate de analist al vieții interioare. Pornind de la perceperea emoțiilor în relaţie cu efortul de a accesa lumea spirituală, lucrarea investighează influența celor două fenomene din spațiul cultural francez asupra dezvoltării unui vocabular al afectelor în cadrul literaturii române interbelice. În lucrare, „influența” este definită drept un fenomen „difuz, aproape indescifrabil, adeseori inconștient” (Maxime Decout, Qui a peur de l'imitation), care solicită autorului ce reinterpretează importul, selecția și, în cele din urmă, adaptarea. Această perspectivă este corelată, pe de o parte, cu teoria emoțiilor dezvoltată de Maurice Halbwachs, prin care emoțiile sunt descrise ca un instrument atât pentru asigurarea coeziunii grupului, cât și pentru conservarea societății (L'expression des émotions et la société), iar, pe de altă parte, cu teoria lui Frédéric Lordon, care abordează afectele ca efecte ale unei structuri în care individul este constrând involuntar (La société des affects).

Cuvinte-cheie: literatură română, Marcel Proust, configurare afectivă, influență, literatură comparată. 